\title{
Tetramer based approach for efficient identification and isolation of neo-antigen specific CD8 T cells from peripheral blood (PBL) of patients with metastatic cancers
}

\author{
Mini Bharathan', Katarina Trebska-McGowan², Pasetto Anna², Drew C Deniger', Ken-ichi Hanada², Jared J Gartner², \\ James C Yang ${ }^{3}$, Steven A Rosenberg ${ }^{1}$, Paul F Robbins ${ }^{3 *}$
}

From 30th Annual Meeting and Associated Programs of the Society for Immunotherapy of Cancer (SITC 2015) National Harbor, MD, USA. 4-8 November 2015

\section{Background}

Adoptive cell therapy with $\mathrm{T}$ cells bearing mutation specific $\mathrm{T}$ cell receptors (TCR) can be an effective method for treating metastatic cancers. The objective of this study was to identify mutation reactive $\mathrm{T}$ cells in the circulation of patients with different types of metastatic cancer.

\section{Methods}

The strategy utilized whole exome sequencing data to identify somatic non-synonymous mutations and then insilico algorithms to predict minimal epitopes encoding mutated amino acids for each patient specific HLA-allele. CD8-enriched PBL from each patient were stained with tetramers generated in house by a UV-exchangeable tech-

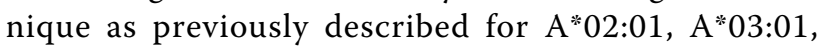
$A^{*} 11: 01, B^{*} 07: 02$, and a commercial tetramer was acquired for B*57:01. Based on the initial staining frequency (+tetramer $^{+} \mathrm{T}$ cells recognizing 7 unique neo-antigens from the PBL of 4 patients (ranging from 1 to 4 per patient). We enriched the frequencies of $\mathrm{CD}^{+}{ }^{+}$tetramer ${ }^{+}$cells from 0.5 to $>85 \%, 0.3$ to $>65 \%$ and 0.01 to $3 \%$ from the PBL of patients with colorectal (3971-A*02:01), lung (4014B*57:01), and ovarian (4067-B*07:02) cancers respectively, using individual tetramers. Populations reactive with three HLA-A*11:0-restricted and one HLA-A*03:01-restricted neoantigens were also isolated from the PBL of lung cancer patients 4014 and 4037, respectively, using a pooled tetramer approach.

\section{Results}

Overall, the isolated $\mathrm{T}$ cells recognized mutated epitopes when co-cultured with autologous $\mathrm{CD} 14^{+}$monocytes pulsed with mutated peptides in the context of appropriate MHC-I alleles including HLA-A*02:01, HLA-A*03:01, HLA-A*11:01, HLA-B*07:02, and HLA-B*57:01, with reactivity detected using IFN- $\gamma$ ELISA. Using single cell PCR, we could clone the TCRs reactive with an HLA-" $02: 01-$ presented colon cancer neoantigen and an HLA-B*57:01presented lung cancer neoantigen. Evaluation of PBL retrovirally-transduced with these TCRs demonstrated that they bound to tetramers and secreted IFN- $\gamma$ when cocultured with $\mathrm{CD} 14^{+}$monocytes pulsed with appropriate mutated peptides.

\section{Conclusions}

To conclude, tetramers offer a sensitive, fast and reliable methodology to isolate mutation specific tumor reactive $\mathrm{T}$ cells from PBL of cancer patients. Furthermore, this method facilitates the identification, and cloning of mutation reactive TCR with which to construct receptorengineered $\mathrm{T}$ cells for adoptive $\mathrm{T}$ cell therapy.

\section{Authors' details}

${ }^{1} \mathrm{NIH} / \mathrm{NCl}$, Bethesda, MD, USA. ${ }^{2} \mathrm{NIH} / \mathrm{NCI}$ Surgery Branch, Bethesda, MD, USA ${ }^{3}$ National Institutes of Health, Bethesda, MD, USA.

${ }^{3}$ National Institutes of Health, Bethesda, MD, USA

Full list of author information is available at the end of the article 
doi:10.1186/2051-1426-3-S2-P47

Cite this article as: Bharathan et al.: Tetramer based approach for efficient identification and isolation of neo-antigen specific CD8 T cells

from peripheral blood (PBL) of patients with metastatic cancers. Journal for ImmunoTherapy of Cancer 2015 3(Suppl 2):P47.

Submit your next manuscript to BioMed Central and take full advantage of:

- Convenient online submission

- Thorough peer review

- No space constraints or color figure charges

- Immediate publication on acceptance

- Inclusion in PubMed, CAS, Scopus and Google Scholar

- Research which is freely available for redistribution

Submit your manuscript at www.biomedcentral.com/submit 